\title{
GRAMSCI EN NUESTRA AMÉRICA A \\ LOS OCHENTA AÑOS DE SU MUERTE: \\ DEBATES Y REFLEXIONES ACTUALES \\ SOBRE SOCIEDAD CIVIL, HEGEMONÍA \\ E INSTITUCIONES JURÍDICO-POLÍTICAS
}

GRAMSCI IN OUR AMERICA AFTER EIGHTY YEARS

OF HIS DEATH: CURRENT DEBATES AND

REFLECTIONS ON CIVIL SOCIETY, HEGEMONY

AND JURIDICAL-POLITICAL INSTITUTIONS

ALBERTO FILIPPI •

Alberto Filippi es docente del Doctorado de Derechos Humanos de la Universidad Nacional de Lanús y profesor de la Escuela del Servicio de Justicia de la Nación.

E-mail: Alberto.filippi@unicam.it

\section{Resumen}

El autor estudia la revisión crítica de la elaboraciones de la «filosofía de la praxis» realizadas por Gramsci en sus Cuadernos (especialmente entre los años 1931 y 34) en torno a la relación entre «Sociedad Civil» y «Sociedad Política» en Hegel y Marx, replanteando (ahora a los 80 años de la muerte de Gramsci) el debate que en los años '70 promovieron Norberto Bobbio y José Maria Aricó, como una etapa fundamental de la comprensión de las principales categorías de la «filosofía de la praxis» y de la consecuente concepción de la «hegemonía política» en la crítica de las instituciones Latinoamericanas.

\section{Abstract}

The Author studies the critical revision of the elaborations about the "philosophy of praxis» made by Gramsci in his Cuadernos (especially between 1931 and 1934) around the relationship between "Civil Society» and "Political Hegemony» in Hegel and Marx, rethinking (now 80 years after Gramsci's death) the debate that in the 1970s was promoted by Norberto Bobbio and José Maria Aricó, as a fundamental stage in the understanding of the main categories of the "philosophy of praxis» in the culture and criticism of de Latin-American institutions. 